\title{
Developing approaches for establishing a fisheries baseline: case-study for Xe Bangfai basin (Lao PDR)
}

\section{Développement d'approches pour l'établissement d'une référence des pêches : le cas d'étude de la Xe Bangfai (Laos)}

\author{
T.A.M. Visser ${ }^{(1)^{*}}$, M. Ovenden ${ }^{(1)}$, N. Wongwai ${ }^{(1)}$ \\ (1) Nam Theun 2 Power Company, Environmental and Social Division, PO Box 5862, Vientiane, Lao PDR \\ 188 group 13, T-Intakin A-Maetang, Chiang Mai 50150, Thailand \\ dangleloo@gmail.com
}

\begin{abstract}
The approach of Fish Catch Monitoring of the Nam Theun 2 hydro power project area is documented and describes the fish catch monitoring methodologies implemented for the period from 2006-2014 with special emphasis on changes in the methods and how data collection has evolved in the Xe Bangfai basin. The collected data aimed at documenting changes in the fisheries (e.g. habitat use, daily household catch, gear use and effort) before and after commencement of electricity generation. The methods used rely on social research methods, i.e. recall surveys and household catch logbooks that are provided and maintained by fishermen. The panel survey has demonstrated is appropriateness to monitor and document changes in the fisheries over time with a high level of confidence at relatively low cost. The households participating in the panel remained relatively stable throughout the survey period. The method tends to overestimate fish catches and under estimate the collection of other aquatic animals. The level of effort (fishing days) is consistent between different surveys. The monitoring results provide a good understanding of trends and changes in the fisheries.
\end{abstract}

Key words - fisheries, monitoring, river, logbook, evaluation

Résumé - L'approche du suivi des pêches au sein du projet hydro-électrique Nam Theun 2 (Laos) est documentée et décrit les méthodes de suivi des pêches mises en place pour la période de 2006-2014 en mettant l'accent sur le changement des méthodes et la façon dont la collecte des données a évolué dans le bassin de la Xe Bangfai. Les données récoltées visaient à documenter les changements observés au niveau des pêches (par exemple l'utilisation de l'habitat, prises quotidiennes des foyers, moyens et effort de pêche) avant et après le début de la production d'électricité. Les méthodes utilisées s'appuient sur des méthodes de recherche sociale, à savoir les enquêtes faisant appel à la mémoire et les registres quotidiens des prises des foyers qui sont fournis et entretenus par les pêcheurs. Cette enquête par panel a démontré sa pertinence pour suivre et documenter les changements observés au niveau de pêches au fil du temps, ceci avec un niveau de confiance élevé et à un coût relativement faible. Les foyers participants à ce panel sont restés relativement stables sur la 
durée de l'enquête. Les méthodes ont tendance à surestimer les prises de poissons et à sous-estimer les prises des autres animaux aquatiques. Le niveau d'effort fourni (en jours de pêche) est cohérent entre les différentes enquêtes. Les résultats du suivi fournissent une bonne compréhension des tendances et changements des pêches.

Mots-clés - pêches, suivi, rivière, registre, évaluation

\section{INTRODUCTION}

Fisheries are a major activity for many people living in inland and coastal areas and are considered to be the major source of protein for rural populations. Information on actual levels of consumption and catch are scant, but research data suggest that for example the inland capture fisheries in the Mekong basin may produce over 3 Million tons (Mt) per annum (Hortle \& Bush, 2003). The official catch estimates, where available, do not even come close to this amount and may underestimate the actual fish production with a factor of 2 to 3 times.

Inland fisheries are not a homogenous collection of fisheries, as there are many different levels of operation, down from collection by hand by family members to almost industrial sized operations (e.g. Dai fisheries in the Tonle Sap, Cambodia). Although a few localized commercial fisheries of middle to large scale can be observed, most of the operations are small one man/household sized operations (often family business or small enterprises) that are scattered in space and time, using a wide array of gears and habitats for catching a wide variety of species.

The fishing activities often have a large subsistence component, with many fishers active only for part of the year. Even for commercial fishermen, fishing is often only one of the livelihood activities. Since most fishing activities tend to occur early in the morning, even a full-time (professional) fishermen may be back home before 10 in the morning, with earnings from that day's catch. This leaves enough time for other activities and indeed it is rare for fishing to be the only source of income. However, for most households, fishing is a subsistence activity and a source of incidental income when more is caught than the household needs for consumption.

Reservoir, river and floodplain fisheries are all characterised by fixed fishing grounds, seasonal differences in catches (Fig. 1) and species composition, with both formal and informal landing sites and fish trade systems. Fisheries have a close relationship with their environment and are therefore the prime focus of recent participatory management approaches.

Due to the inherent dynamics of inland waters, the heavy dependence on floodplains in river fisheries, either directly (floodplain fisheries) or indirectly (much of the catches, i.e. biological production, in rivers and reservoirs is actually produced on the floodplains), there may be huge fluctuations in production from one year to another, that are largely unrelated to the fishing pressure. It has been widely acknowledged that floodplains are the engine that drives riverine fisheries (flood pulse concept; Junk et al., 1989), and 


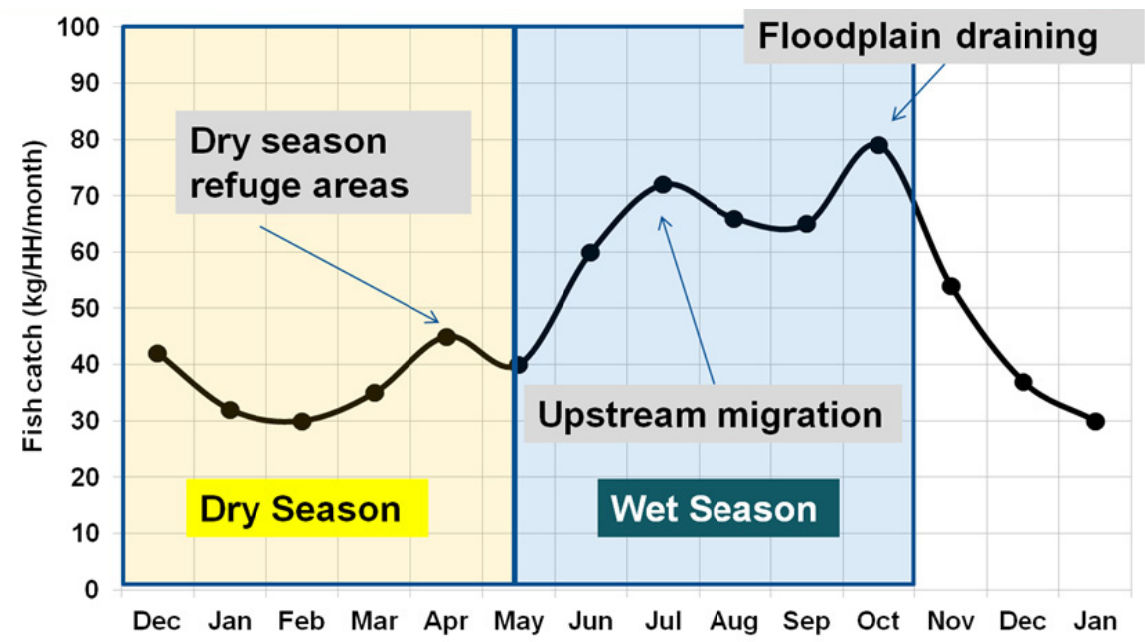

Fig. 1. Generalised catch graph for a Mekong tributary with floodplain.

Fig. 1. Graphique généralisé des prises pour un affluent du Mékong avec sa plaine d'inondation.

this is well documented (Welcomme, 1975; Hoggarth et al., 1999; de Graaf et al., 2001). There is a strong correlation between the level, extent and duration of flooding events and the fish catches in that and subsequent years. Fisheries in rivers are floodplain driven, because this is where many of the juvenile fish spend the early stages of their lives and this is most productive in terms of fisheries.

Complex relationships between habitats, fish and flooding create a far more complex and dynamic fisheries system in inland areas than in marine coastal fisheries or lakes and reservoirs. Participation, gear use and catches fluctuate between seasons and years, as well as in response to economic factors. As a consequence, inland fisheries are more difficult to monitor than coastal fisheries and care has to be taken not to simply transpose marine methodologies and concepts to inland fisheries. When reviewing manuals and guidelines for the collection of fishery statistics (Reyntjes, 1997; Stamatopoulos, 2002), these tend to focus almost exclusively on sample surveys for catch and effort at landing sites or on fishing surveys using experimental fishing (Kolding, 1989). This relies on direct measurement of fishery parameters (catch and effort) by data collectors. These are both valid approaches when the fisheries is mainly commercial in nature, with central landing sites that can be sampled to provide representative information on the fisheries or in cases when the fisheries is largely uniform in time. However for inland fisheries, especially riverine fisheries, most trade is informal with the fisheries typified by a large subsistence component and an important seasonality in the fisheries that causes large shifts in effort and fishing locations. This makes it difficult to assess the fisheries and 
changes in operations with direct sampling methods that would only cover commercial operations, while experimental fishing may only reveal the catch potential, not what truly is happening in the fisheries.

The main focus for fisheries monitoring for Nam Theun 2 Power Company (NTPC) based on Concession Agreement (CA) requirements is to assess natural change and trends in the fisheries, between seasons and years and evaluate impact from NT2 operations on the fisheries after Commercial Operations Date (COD) until mid-2015.

This requires that all aspects of the fisheries need to be covered, both commercial and subsistence components. Using the standard approaches of either direct measurement or experimental fishing, chances are that subsistence fishing would be underrepresented, lessening the utility of the data. The choice then is between a number of alternative approaches that focus on assessing fisheries parameters directly (catch/effort assessment) or indirectly (consumption studies). Because the CA specifies fisheries monitoring that includes a focus on key fishing parameters and levels of impact on catches and dependency after COD, consumption studies would not provide sufficient detail. Although food consumption studies have been conducted this has been done to monitor nutrition and health trends and the data is not suitable for catch assessment.

Establishing a fishery baseline needs to cover a number of years in order to capture the variation between years and to establish any long-term trends in the fisheries. Comparing the multi-year baseline fishery indicators with the situation after the COD will allow assessing impact by NT2 operations, but only after multiple years of post-COD monitoring.

Widely implemented alternatives to direct measurement of catch and effort mainly rely on interview and logbook based methods, where households are the source of information on the fisheries and catches. Various participatory data collection systems exist and are well documented (FAO, 1999; Visser, 2003). Compared with direct measurement methods, these participatory monitoring approaches allow capturing information on both subsistence and commercial fishing operations, thereby increasing the representativeness of the data collected. The main drawback is that the data become less precise and that it depends heavily on the willingness and ability of participants to accurately recall the amounts caught either for recording in a daily logbook, or when interviewed afterwards.

This paper attempts to show how community science (social research methods) can be used as a valid tool for obtaining information on indicators and trends in inland fisheries. For that, the study will focus on the fish catch monitoring methodologies implemented for the period from 2006-2014 with special emphasis on changes in the methods and how data collection has evolved. No data beyond 2009 will be shown as the correct interpretation of the data after COD requires the full data set to be available and this is expected to be covered in a later article, however a few examples of data obtained from the surveys will be included for the baseline period prior to 2010 . 


\section{FISH CATCH MONITORING METHODS}

\subsection{Study site}

The Nam Theun 2 hydro-power project is situated in Khammouane province, Lao PDR (Fig. 2). NTPC is the company formed by the Lao Government and the private shareholders in the Nam Theun 2 Hydroelectric Project to build and operate the Project for the first 25 years of its operation. The impoundment of the Nam Theun 2 Reservoir, on the Nakai Plateau, will lead to the creation of a $489 \mathrm{~km}^{2}$ reservoir at its full supply level. The main characteristic of this project is to divert water from the Nam Theun basin (from Nam Theun 2 Reservoir) to the $\mathrm{Xe}$ Bangfai basin southwards through the NT2 Downstream Channel that empties into the Xe Bangfai River, a Mekong tributary. All the main features of this project are detailed in Descloux et al. (same issue). Among the different divisions of the NTPC, the Environmental and Social Division (E\&S) implements comprehensive programs on resettlement and livelihood assistance, public health support and environmental and biodiversity monitoring and mitigation programs. The activities implemented by E\&S are based on the requirements included in a CA between NTPC and the Lao Government. The CA specifically calls for a fisheries monitoring program to establish pre-project fishery resources baseline of 5 years in portions of the downstream area affected by the operation of the NT2 project. The monitoring program is required to continue using the same fish monitoring instruments and sampling design, during 5 years after COD (in April 2010), to assess changes in the fisheries related to the trans-basin release of water from the Nam Theun basin into the Xe Bangfai River. Indeed, the lower reaches of the Xe Bangfai basin are characterised by floodplains, while the upper reaches feature the Xe Bangfai River in a narrow gorge with occasional floodplain areas around the mouths of tributaries. Natural mainstream flow is low during the dry season, with extensive flooding of the floodplains in the Lower portion of the Xe Bangfai during the rainy season (Fig. 3). After COD water released by the project will increase dry season flow above typical average dry season values. Flow during the rainy season is expected to be undistinguishable from that during pre-COD years.

Furthermore, the region is known to host a large number of fish species. Kottelat (2001) identified more than 481 species for the whole of Lao PDR, with estimates for the Xe Bangfai basin ranging from 130 (Phonvixay, 2013) to 157 including 38 migratory species (Ziv et al., 2012).

The Fish Catch Monitoring surveys (FCM) cover three distinct areas (Fig. 2) which are (i) the Nakai watershed area, (ii) the downstream of the Nakai Dam (Khamkeut District); and (iii) the area downstream of Power House in the Xe Bangfai watershed. The current article focuses on the downstream area of the Xe Bangfai River (Xe Bangfai). As Figure 2 shows, this area is divided in 5 distinct areas. The Nam Gnom/ Nam Kathang area is omitted for this article. The fisheries here are monitored, but this was mainly done to assess impact by construction 


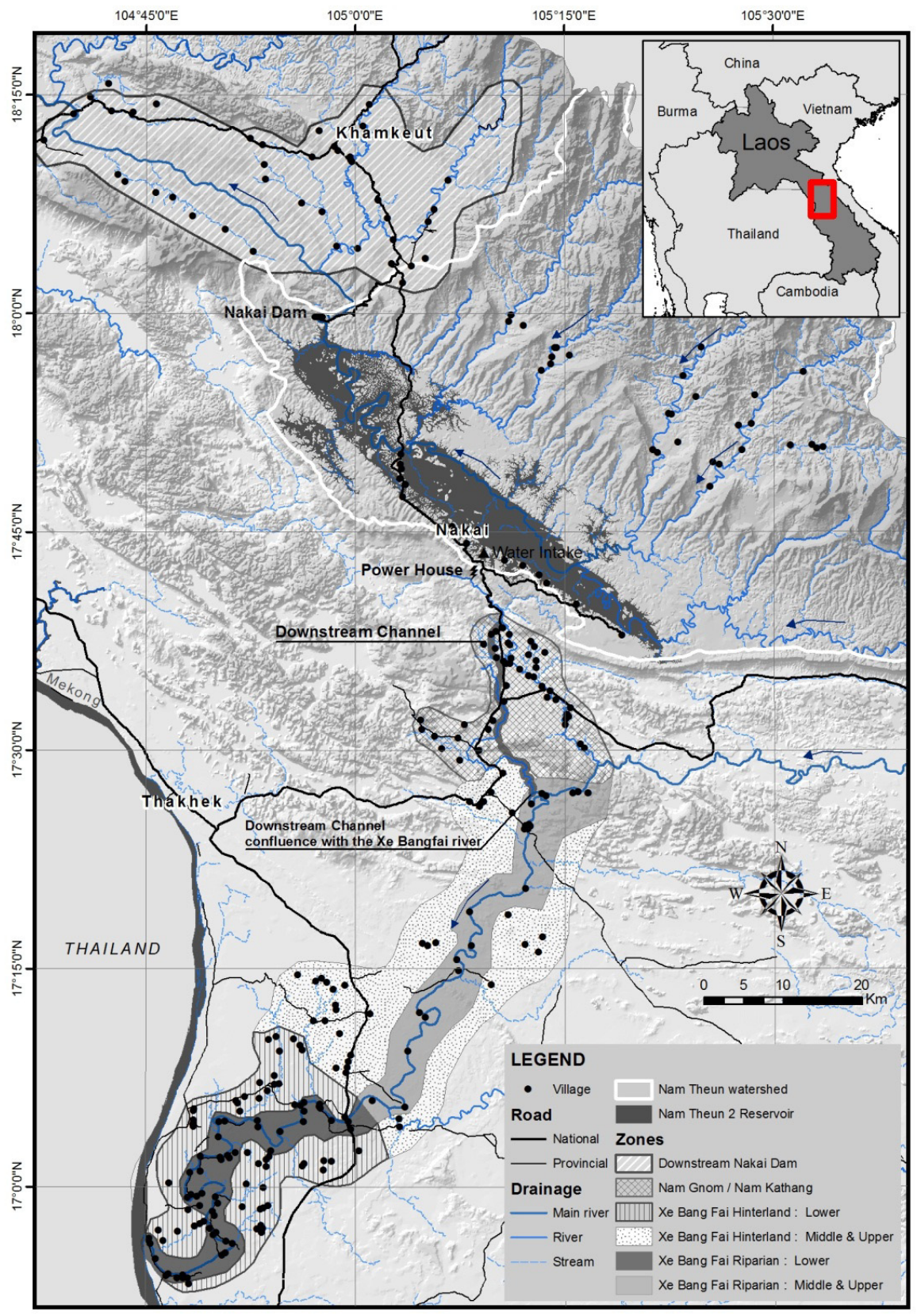

Fig. 2. Overview of analytical zones and village locations for social and environmental surveys.

Fig. 2. Présentation des grandes zones représentatives et localisation des villages pour les enquêtes socio-environnementales. 


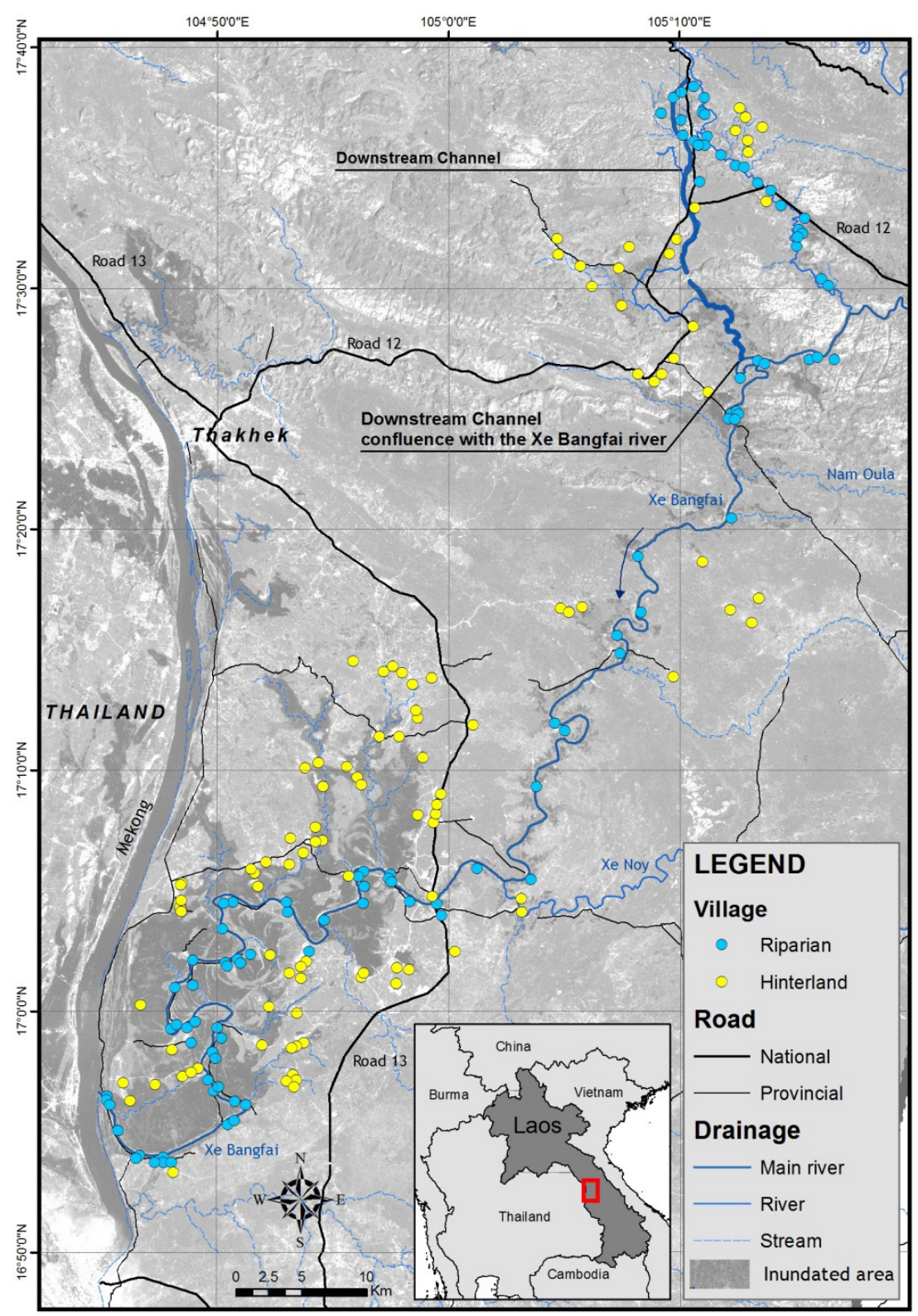

Fig. 3. Overview of Xe Bangfai basin with location of riparian and hinterland villages as well as finundated areas at peak flooding (based on satellite imagery for August 2004).

Fig. 3. Bassin de la rivière Xe Bangfai avec l'emplacement des villages riverains et de l'arrière-pays ainsi que les zones inondées en période de pointe des crues (basée sur l'imagerie par satellite d'août 2004). 
Table I. The sample coverage by analytical zone for the Xe Bangfai (XBF) downstream area. Tableau I. Couverture de l'échantillon par zone représentative pour la partie aval de la Xe Bangfai.

\begin{tabular}{|l|c|c|c|c|c|}
\hline \multicolumn{1}{|c|}{ Analytical zone } & Villages & $\begin{array}{c}\text { Total } \\
\mathrm{HH}\end{array}$ & $\begin{array}{c}\text { Village } \\
\text { sample }\end{array}$ & $\begin{array}{c}\mathrm{IHI} \mathrm{HH} \\
\text { sample }\end{array}$ & $\begin{array}{c}\mathrm{DCL} \mathrm{HH} \\
\text { sample }\end{array}$ \\
\hline XBF Gnom/Kathang & 21 & 3,207 & 7 & 137 & 35 \\
\hline XBF Upper-Middle Hinterland & 17 & 1,705 & 3 & 53 & 15 \\
\hline XBF Upper-Middle Riparian & 24 & 1,885 & 9 & 176 & 45 \\
\hline XBF Lower Hinterland & 56 & 9,086 & 4 & 117 & 20 \\
\hline XBF Lower Riparian & 41 & 5,851 & 8 & 231 & 40 \\
\hline
\end{tabular}

The $\mathrm{VCl}$ covers all villages in the project area. $\mathrm{HH}=$ Households, $\mathrm{IHI} \mathrm{HH}=$ households sampled for household interview survey and DCL HH = households sampled for the Daily Catch Logbook survey.

and not by commercial operations and follows a slightly different method. Furthermore villages in this area don't fish in mainstream Xe Bangfai. The survey area covered by the fisheries monitoring for the Xe Bangfai basin comprises almost 22,000 households in over 160 villages.

\subsection{Village selection}

Preliminary assessments during 2002-2005 indicated that NT2 operations might strongly affect households located in villages close to mainstream Xe Bangfai, with villages directly downstream of the confluence between the Xe Bangfai and the NT2 Downstream Channel (DC) expected to be more affected than villages in the Lower Xe Bangfai. For this reason relatively more villages were selected in the Upper and Middle Xe Bangfai to allow for a better coverage of the fisheries in this area.

The villages were selected based on the importance of fisheries in terms of the number of households that depend heavily on fishing (as ascertained in preliminary Village Community Interview surveys during 2005) (Tab. I). This means that the villages were not selected at random, but represent areas with a higher than average fisheries dependence and which can be used to better assess changes over time and after COD. The resulting sample coverage is indicated in Table I.

Since villages close to the river tend to depend more on fisheries than villages that are further away from mainstream channel, villages were sampled from two groups: riparian and hinterland villages. Access for conducting interviews and collecting logbooks is important and for this reason some villages were excluded from the sample in part because they become difficult to access during the wet season.

\subsection{Description of the Fish Catch Monitoring surveys}

Three main surveys were designed to enable assessing the fisheries 
including catch estimates at three levels for verification and calibration (Tab. II):

(i) Village Community Interview ( $\mathrm{VCl}$ ) including fishing location mapping and impact assessment for all (230) villages in the project area;

(ii) Individual Household Interview (IHI) using 6-monthly recall survey obtaining monthly catch assessment for a random sample of 720 households in 51 villages; and

(iii) Daily Catch Logbook (DCL) for monitoring of daily household catches by 5 pre-selected monitoring households $(\mathrm{HH})$ in 51 villages.

These three levels of information gathering were based on a similar approach implemented by the Mekong River Committee (MRC) Assessment of Mekong Fisheries Component (Sjorslev, 2000; Suntornratana, 2002; Phan et al., 2003) that was adjusted to the requirements of the NTPC surveys.

All data collection is through paper survey forms and interviews. Except for the Daily Logbook survey (DLC), for which fishermen must complete a logbook form on their own for each fishing day, the other surveys are using the survey form for data recording and use question and answer sessions for obtaining the information from respondents. Data collection started in early 2006 and will continue until the end of April 2015. The monitoring also includes the Other Aquatic Animals (OAA) which are water insects, snails, shells, crabs, shrimp and frogs (but not water birds or mammals/turtles).

The priority for the NT2 FCM program is on establishing trends in the fish catch, fishing effort and habitat use in order to create a fisheries baseline and subsequently assess the level of impact from NT2 operations. Therefore it is important to use the same methodologies during the entire duration of the survey period, so data collected is comparable. This will allow for comparisons to be made before and after COD to assess the impact on fisheries without needing a high level of accuracy of individual data points. However despite the best efforts and planning, some adjustments and modifications in the methodology were inevitable.

An overview of the main methodologies used is included in Table II, with a more detailed description of all main survey tools used and changes implemented below.

\subsubsection{Gillnet catch survey}

A gillnet survey was implemented from 2001 to 2003 and used a catch logbook to monitor the catch per unit of effort for 21 fishermen fishing in mainstream Xe Bangfai from seven riparian villages. The survey collected data for one fishing day per week, for a limited number of gillnet types. It was discontinued because the results of the study did not provide estimates for the catch and project managers felt that the $\mathrm{CA}$ called for a more robust and comprehensive monitoring system.

\subsubsection{Village Community Interview}

All villages in the project area which may potentially be impacted by NT2 Project are covered by a Village Community Interview, or VCl. Data is 


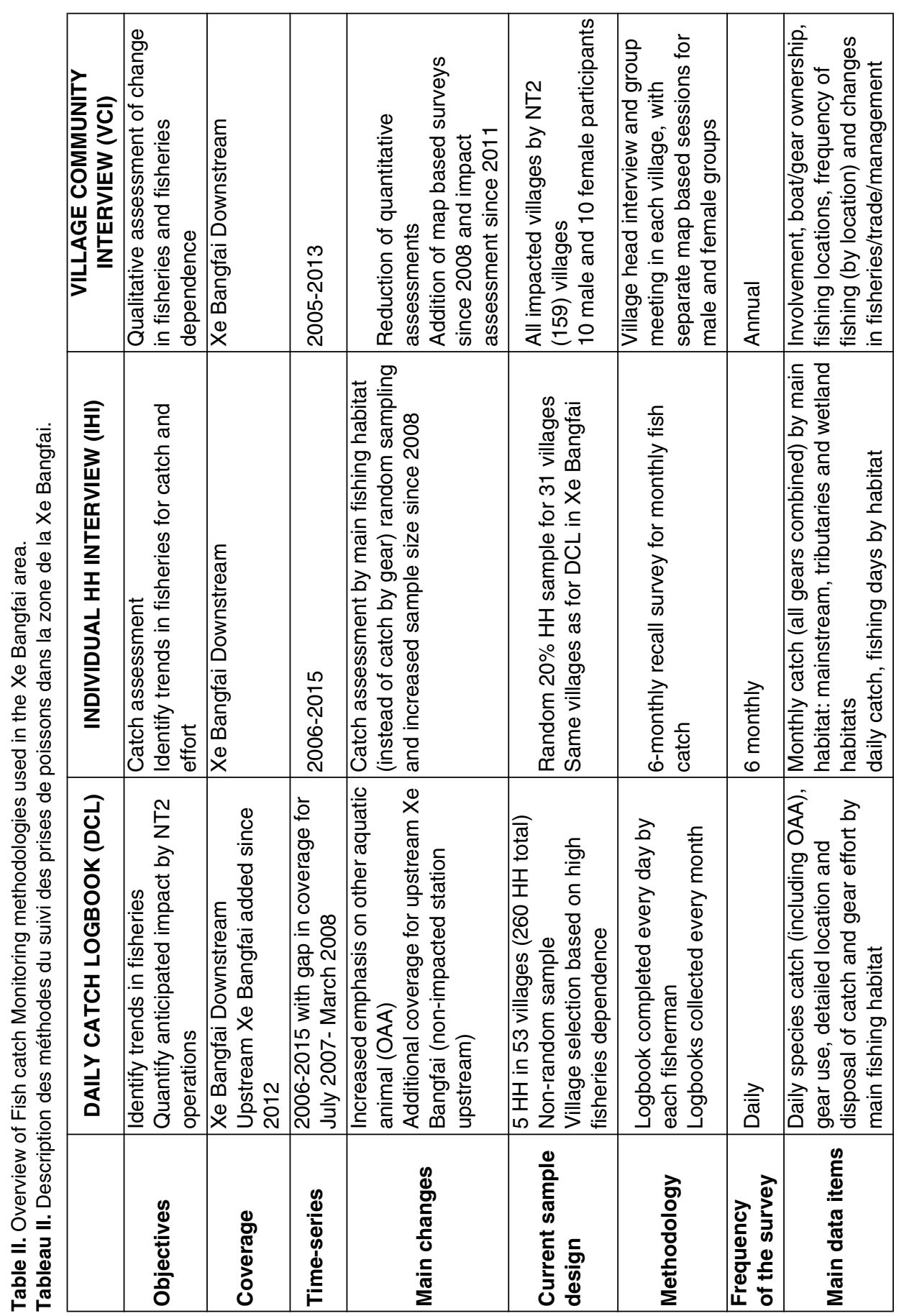


obtained using fishery focused questions in (large) annual village group meetings where for the first 3 annual surveys the target was to have at least $20 \%$ of the households in the village present. Because of high attendance, but without active participation of most of the community members present, this was later changed to have around 10 male and 10 female participants for a more balanced gender representation and to ensure that attendees were in fact participating in the discussions. This survey is generally conducted at the beginning of each year covering the fisheries in the previous year, but later surveys have been done throughout the year as the $\mathrm{VCl}$ is not time critical.

The meeting was implemented in two parts (i) an initial survey with village leaders to identify general management and fisheries parameters and (ii) a second survey where community members were invited for a village meeting to answer and discuss a list of questions concerning the fisheries.

The $\mathrm{VCl}$ does not have a fixed structure or coverage, this means that the topics discussed and the focus for the information gathered changes with each survey. Earlier VCl's were heavily focussed on collection of quantitative data (catch assessment, gear ownership, species catch and household dependency), with later VCl's shifting to a more qualitative approach.

Recognising that the exact estimates on certain aspects of the fisheries were not compatible with the more detailed assessments obtained from the Individual Household Interview survey (IHI) and Daily Catch Logbook survey (DCL) surveys, the focus for the $\mathrm{VCl}$ shifted more towards assessment of change in fisheries. For the $\mathrm{VCl}$ survey for 2008 (conducted in 2009), a more participatory method using village mapping was implemented to obtain the location of community ponds, large scale gears and conservation areas. Instead of asking for the location, participants to the $\mathrm{VCl}$ survey were asked to draw village resource maps. A similar survey was initiated for the $2011 \mathrm{VCl}$ (conducted in 2012), with the addition of specific questions for impact/change in catches and habitat importance and a more detailed implementation of catch assessment all connected to the community mapping

\subsubsection{Individual Household Interviews}

A sample of fishermen each representing their household is interviewed individually using a detailed questionnaire to assess fishery activities in different habitats for their household, twice a year with a recall period of 6 months. This survey is conducted in the same villages selected for coverage by the DCL survey. Each village initially was covered by interviewing a fixed number of 20 households, including the households involved in the DCL survey. Households were selected from 3 categories in the ratio 6-10-4 from experienced, intermediary and inexperienced fishing households (obtained from early Village Community Interview survey). The households are interviewed for January-June and July-December periods with total catch estimates (not separated by species) by month for all gears combined (with initially a separate estimate for gillnets) focusing on mainstream habitats with catches for all other habitats grouped together. 
A random sample was introduced at the beginning of 2008 , with some additional improvements to the survey form, to reflect the emphasis on catch by habitat and increase attention for collection of other aquatic animals.

The new sample size is approximately equal to $20 \%$ of the number of households in the villages covered and thus varies depending on the number of fishing households in each village to improve representativeness for the fishing activities and catches. The interview technique has not changed (except for more emphasis on fishery related activities by other household members). The coverage has improved and due to the random sampling a better estimate for the catch and active fishing households (equivalent to effort) is achieved ${ }^{1}$. The sample size has also increased from 620 households before 2008 to 720 from 2008 onwards for the Xe Bangfai basin. The IHI survey is implemented in the downstream area of the Xe Bangfai and in the Nam Kathang/Gnom area surrounding the Downstream Channel.

\subsubsection{Daily Catch Logbook}

The most detailed methodology used is the DCL survey. A sample of 5 fishing households per village is selected to fill out a daily catch monitoring form to collect detailed quantitative catch data for all household members in 51 villages. Although households

(1) The pre-2008 can be considered a pseudo-random sample as the information on the dependency of the household on fisheries from the $\mathrm{VCl}$ is tentative at best, therefore the impact of implementing a true random sample are likely to be small. were selected according to a fixed ratio between experienced, intermediate and inexperienced fishing households, in practice the selection shows a bias towards fishing households that fish regularly during the entire year with reading/writing skills. Selection was facilitated by the village headman. Training is provided to the fishing households to ensure proper documentation of fish catch. Record keeping forms and weighing scales are also provided to each of the household monitors to ensure the quality of data. The form covers:

(i) fish catch by gear, catch by species, effort (gear units) and detailed fishing location;

(ii) fish catch disposal for household consumption, sale and processing; and

(iii)aquatic animals and plants collection and disposal.

In view of the importance of accuracy and the independence required for this survey, a considerable effort is made to train fishermen in all aspects of data collection and recording at the onset of the survey and whenever new replacement households are selected. This remains a high priority throughout the survey with monthly feedback on data submitted and annual refresher workshops to discuss issues found with the data submitted as well as results of the survey.

Logbooks come as bound monthly logbooks with a page for each calendar day, to cover all fishing activities by all household members. Forms are checked by field staff before being submitted for data entry, issues found are discussed with the household catch 
monitor and data adjusted when necessary. Most mistakes are with weights that are inconsistently recorded, names for fishing habitats and issues with species names.

Species names are recorded as Lao common names on the form and in most cases the species lists used by the households for the DCL is obtained from species lists compiled during the $\mathrm{VCl}$ survey. The common name is linked to a scientific name by showing a fish species photo flipchart, the link between Lao common name and scientific species name has been verified for a selection of villages without finding any discrepancies with the existing linkages.

\subsubsection{Socio Economic Profile}

In order to assess the fisheries dependency of all households participating in the DCL, a survey was done to cover the relative importance of fishing as a livelihood as well as for food consumption. The survey was also used to record household composition, land resources and assets, boat and gear ownership and relative skill in fishing. The survey is done only once for each household, replacement households are surveyed whenever they enter the DCL survey.

\subsubsection{Verification survey}

The verification survey was designed to compare the catch by a representative group of households with that reported by the households involved in the DCL, to see if the DCL data is representative for all households for total catch and fishing days.
The survey was implemented in 9 random selected villages also covered by the DCL survey, in which a total of 143 households were interviewed on their total catches in the previous 5 days. This survey was repeated during 7 separate 5 days periods from early November 2011 to early March 2012 taking a 10\% random sample of households.

\subsubsection{Field observation reports}

Multi-day field trips are organised by the data collection team to cover selected villages in the upper, middle and Lower Xe Bangfai. In each village fishermen and traders are approached to talk about fishing, levels of catches, trends over time, fish prices and any fisheries related issues encountered. This survey is implemented every 3 months and serves as a supplemental source of information on trends in the fisheries that can be used to interpret the findings of the analysis.

\subsection{Data collection}

Several changes have been made in how the data is collected and processed to improve both quality and timeliness of the data, leading to a more robust and reliable system.

\subsubsection{Staffing}

During the early stages of the monitoring program, District staff were used part-time to implement the surveys supervised by a NTPC field co-ordinator. In view of the workload, the status of these staff was changed to NTPC 
staff to allow them to work full-time on data collection and also to facilitate work outside of their designated district. The field team consists of 6 fulltime data collectors and one field coordinator, supported by an external consultant for survey design, analysis and report writing.

\subsubsection{Data verification}

All data is verified on the forms by data collectors right after a survey interview is conducted, with any issues addressed on-site while the respondents are still available. A second verification is conducted by the field co-ordinator on a sample of forms before they are submitted for data entry. This focuses on ensuring data provided is internally consistent (using safeguards built into the survey forms), complete and legible, as well as to flag any inconsistencies or outliers in the data for clarification.

\subsubsection{Database}

All data is entered into a database when internal data checks are performed to ensure that no mistakes are made, using a standard Quality Assurance and Quality Control (QA/QC) protocol for partial double data entry. This ensures that data is entered with the least amount of mistakes while keeping track of progress of data entry on a continuous basis. Any remaining issues in the data forms are flagged and sent back to the field team for clarification. The databases themselves have been adjusted to make analysis easier, e.g. adding unified codes for habitats and species as well as consistently code
Lao language responses into Lao and English categories.

\section{RESULTS}

The results of the FCM program can be separated into two categories which are (i) outcomes from the changes that have been implemented in the methodology and (ii) data obtained from the surveys.

\subsection{Overall results}

The improvements in the data collection has resulted in far less errors in both data recording and data entry, while the data is available for analysis earlier after data collection. During the first few years of data collection, data from the DCL survey was not available until 5-6 months after recording by the households (fully checked and entered) from all participating households, this delay was reduced to less than 3 weeks for the data for the Xe Bangfai basin. Forms are submitted more timely, complete and with considerable less errors, while corrections are made far more quickly.

Additional data available from both the Socio Economic Profile (SEP) and the field observation surveys have provided valuable insights in trends in the fisheries and make it easier to generalize the findings from the main surveys. The introduction of the mapping component for the $\mathrm{VCl}$ has been instrumental in obtaining more meaningful information on trends in the fisheries for villages not covered by the $\mathrm{IHI}$ and DCL surveys. 


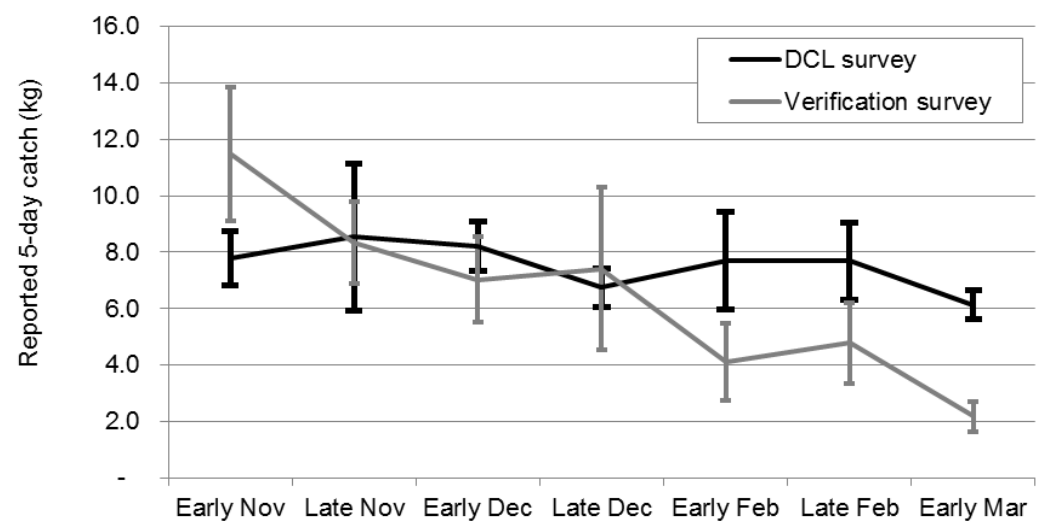

Fig. 4. Reported average 5-day household fish catches $(\mathrm{kg})$ compared between DCL and Verification surveys.

Fig. 4. Moyenne de 5 jours de prises de poisson par foyer $(\mathrm{kg})$ selon le $\mathrm{DCL}$ et le suivi de vérification.

Improvements to the structure of the database and additions of codes and translations of certain aspects of the data make it easier to analyse the data, with some tools added for calculating a number of routine indicators for the fisheries.

Despite the emphasis on relative changes in the main fishery parameters, it is interesting to see how well the data from the DCL survey represents the households in the survey area, as a good match would allow the trends from the DCL sample to be generalised to all households.

The results of Figure 4 compare the average 5-day catch for all households sampled for the DCL and verification survey. They indicate that on average the DCL over estimates the total amount fish reported. Furthermore, it is more severe during the dry season when the DCL over estimates the reported catch by a factor of 2 , while during the late flood season it under estimates the real household catches slightly. As indicated by the error bars that represent the $95 \%$ confidence interval of the mean, the difference is significant for the late dry season, but not for the late wet season and early dry season. The number of fishing days is estimated accurately by the DCL survey.

The DCL consistently under estimates the total reported OAA and the daily OAA catch over all periods surveyed by a factor of 2 , for all but the late dry season (Fig. 5). OAA is an important component of the household consumption, constituting typically $25 \%$ of the combined household catch. The difference between the two data sets is significant for the late wet season, but not for the early and late dry season.

\subsection{Baseline results}

In the following section a few examples are provided of the type of data that is available from the DCL survey 


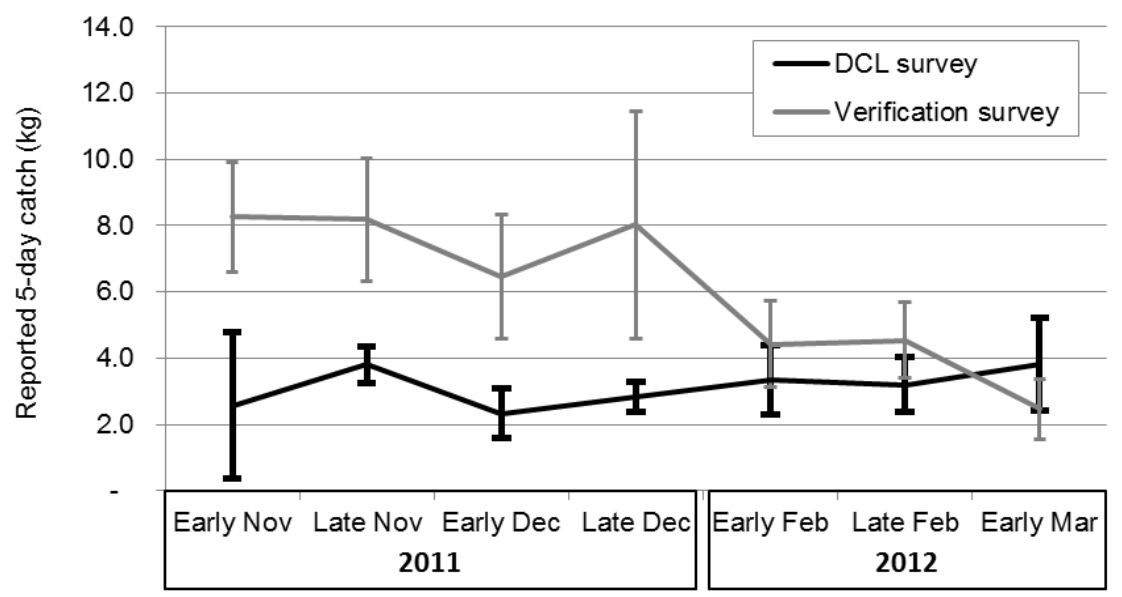

Fig. 5. Reported average 5-day household OAA catches $(\mathrm{kg})$ compared between DCL and Verification surveys.

Fig. 5. Moyenne de 5 jours de prises des autres animaux aquatiques (OAA) par foyer $(\mathrm{kg})$ selon le DCL et le suivi de verification.

with a brief analysis of the main fisheries parameters for the period 20062009 , period before the COD. Note that a decision was made in 2007 to pause the DCL for 9 months for evaluation of the data collected, while other fisheries surveys, $\mathrm{IHI}$ and $\mathrm{VCl}$ continued.

\subsubsection{Species catch}

The 6 species for which data is provided (Tab. III) constitute more than $45 \%$ of the total reported catch in the 2009 data covering a total of over 130 species and species groups present in the available data. The comparison of the average monthly reported catch between years (Tab. III) shows that the catfish Hemibagrus sp. (mainly $H$. wyckioides) is in decline. This is also clear for the cyprinids Puntioplites falcifer and Labiobarbus leptocheila, while both Hypsibarbus sp. and Cosmochilus harmandi stay relatively stable in the catches. Both of these cyprinid species experienced an increase in 2008. The snakehead fish Channa striata also experienced a high increase in 2008.

\subsubsection{Fishing days}

The median reported fishing days are plotted (Fig. 6) for the three main habitats from the DCL survey which are respectively the river mainstream, tributaries, streams, and wetlands. Results show clearly that mainstream habitats are the most important for fishing. There is a very clear seasonality with the lowest number of fishing days for mainstream habitats recorded during peak flow periods during July and August when fishing in mainstream 
Table III. Comparison of the total reported monthly catch for period April-December (kg) from 2006, 2008 and 2009. Result details are provided for the 6 main species catch.

Tableau III. Comparaison de la prise mensuelle totale signalée d'avril à décembre $(\mathrm{kg})$ de 2006, 2008 et 2009. Les résultats pour les 6 espèces principales sont détaillés.

\begin{tabular}{|c|c|c|c|c|}
\hline Main species & 2006 & 2008 & 2009 & Ecological information \\
\hline Hemibagrus sp. & 606.1 & 396.3 & 314.8 & $\begin{array}{l}\text { Longitudinal and lateral migratory, } \\
\text { mainstream and tributaries, depending on } \\
\text { species omnivorous and/or carnivorous; } \\
\text { large bodied species }>50 \mathrm{~cm}\end{array}$ \\
\hline Hypsibarbus sp. & 417.4 & 530.9 & 465.1 & $\begin{array}{l}\text { Longitudinal and lateral migratory, } \\
\text { mainstream and tributaries, omnivorous; } \\
\text { up to } 50 \mathrm{~cm}\end{array}$ \\
\hline $\begin{array}{l}\text { Cosmochilus } \\
\text { harmandi }\end{array}$ & 356.1 & 410.4 & 342.6 & $\begin{array}{l}\text { Lateral migratory, main rivers and } \\
\text { floodplains, omnivorous; around } 10 \mathrm{~cm}\end{array}$ \\
\hline Puntioplites falcifer & 389.7 & 361.5 & 279.1 & $\begin{array}{l}\text { Longitudinal and lateral migratory, } \\
\text { mainstream as well as standing water } \\
\text { including floodplains, omnivorous; } 35 \mathrm{~cm}\end{array}$ \\
\hline $\begin{array}{l}\text { Labiobarbus } \\
\text { leptocheilus }\end{array}$ & 332.5 & 252.3 & 177.8 & $\begin{array}{l}\text { Probably Dangila kuhli or } D \text {. lineata. Lateral } \\
\text { migratory, mainstream and tributaries, } \\
\text { omnivorous; around } 20 \mathrm{~cm}\end{array}$ \\
\hline Channa striata & 298.8 & 538.2 & 384.9 & $\begin{array}{l}\text { Lateral migration to floodplains, standing } \\
\text { water or slow flowing streams, carnivorous; } \\
\text { Large up to } 90 \mathrm{~cm}\end{array}$ \\
\hline $\begin{array}{l}\text { Contribution to } \\
\text { total catch of top } \\
6 \text { species }\end{array}$ & $44 \%$ & $43 \%$ & $45 \%$ & \\
\hline $\begin{array}{l}\text { Average monthly } \\
\text { total reported catch }\end{array}$ & 5462 & 5830 & 4361 & \\
\hline
\end{tabular}

2007 is omitted because only data for the first 6 months is available; ecological information obtained from MRC (2003).

habitats is limited. During the wet season tributaries and wetlands experienced a peak in the effort and can temporary become more important for fishing than mainstream habitats. The fishing effort for tributaries and wetlands tends to be very similar over the years and between years.

\subsubsection{Daily household catch}

If the median reported daily household catch is plotted (Fig. 7), it shows that the three habitats are fairly similar in terms of daily catch that can be obtained. During 2006-2007, the daily household catch in wetlands is significantly lower than the other two habitats and for the 2008-2009 period, the daily catch for tributaries sees a clear increase for the wet season while the mainstream and wetland catches are very similar in level and seasonality.

A comparison of the median reported daily household catches for the period April-December for 3 years 


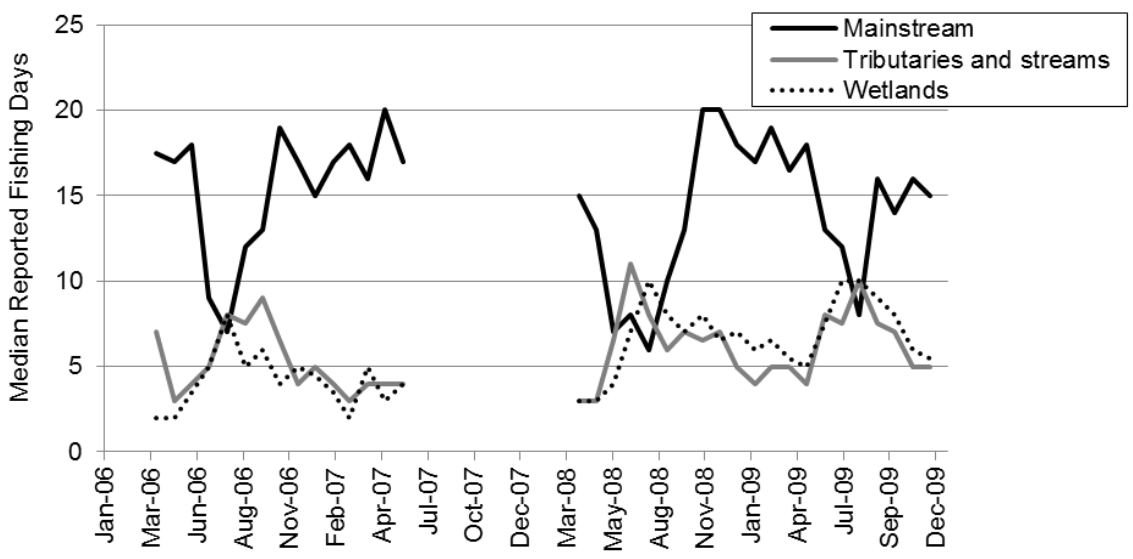

Fig. 6. Median reported monthly fishing days by main habitat from DCL survey.

Fig. 6. Médiane mensuelle des jours pêchés signalés par principaux habitats, suivi DCL.

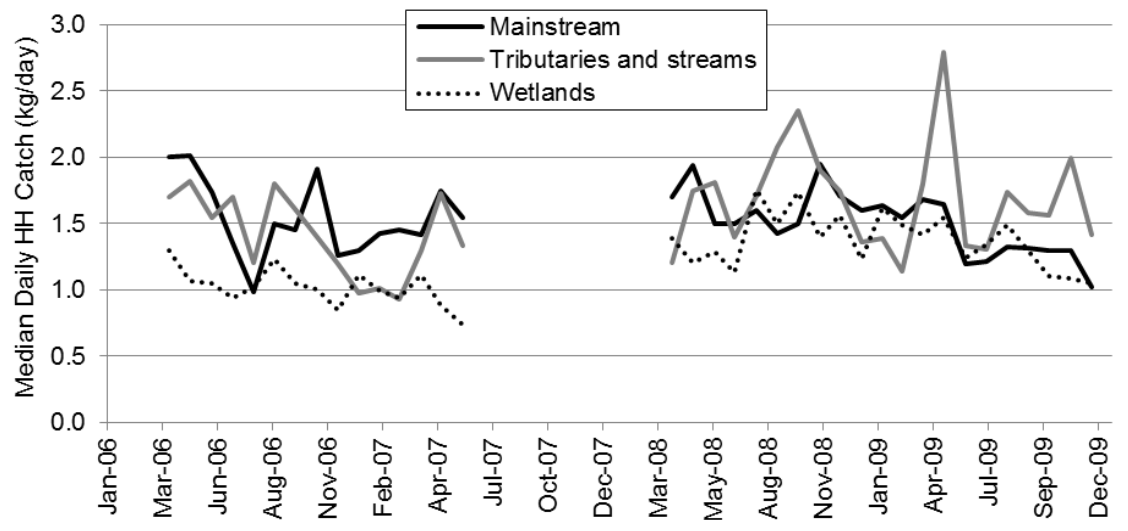

Fig. 7. Median reported daily household catch by habitat $(\mathrm{kg} / \mathrm{HH} /$ day $)$ from $\mathrm{DCL}$ survey.

Fig. 7. Médiane quotidienne des prises par foyer et par habitat $(\mathrm{kg} / \mathrm{HH} / \mathrm{jour})$, suivi $\mathrm{DCL}$.

(2006, 2008, and 2009) (Tab. IV), confirms the trend from Figure 7, with the mainstream catches experiencing a decline between 2006 and 2009, while the daily catches in wetlands see an increase for the same period. In view of the high level of variation, there is no apparent long-term trend at this level of aggregation.
Despite the relative increase in the daily catch for tributaries during 20082009 , compared with other habitats, mainstream habitats contributed close to $65 \%$ of the total catches during 2009 (Fig. 8) with the other two habitats contributing around $18 \%$ each to the total reported catch. The large fishing effort for mainstream habitats is the main 
Table IV. Median reported daily household catch by year and habitat $(\mathrm{kg} / \mathrm{HH} /$ day). Tableau IV. Médiane quotidienne des prises par foyer, par année et par habitat (kg/HH/jour).

\begin{tabular}{|l|c|c|c|c|}
\hline \multirow{2}{*}{ Main habitat } & \multirow{2}{*}{ Overall } & \multicolumn{3}{c|}{ April - December } \\
\cline { 3 - 5 } & & $\mathbf{2 0 0 6}$ & $\mathbf{2 0 0 8}$ & $\mathbf{2 0 0 9}$ \\
\hline Mainstream & 1.50 & 1.50 & 1.60 & 1.30 \\
\hline Tributaries and streams & 1.57 & 1.61 & 1.75 & 1.58 \\
\hline Wetlands & 1.22 & 1.05 & 1.40 & 1.30 \\
\hline
\end{tabular}

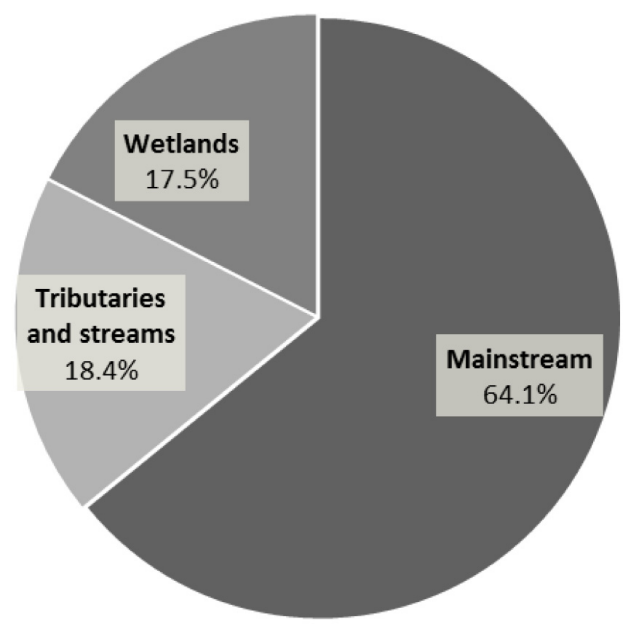

Fig. 8. Contribution by main habitat to the total reported catch for 2009 from DCL survey.

Fig. 8. Contribution des principaux habitats pour les prises totales signalées lors du suivi DCL en 2009.

reason for the large contribution of mainstream catches.

\subsubsection{Gear use}

Gillnets are by far the most important fishing gears in terms of catch $(65 \%)$, followed at considerable distance by hook and line (9\%) and cast nets $(6 \%)$ with other gears (lift net, scoop net, various traps and others) account for $16 \%$ of the catch. Interestingly the mean catch rate for gillnet
(Tab. V) is not the highest, with several other gears, most notably lift net and spear gun having higher catch rates.

\section{DISCUSSION}

The methodology used for the fish catch monitoring is a result of a necessary compromise between accuracy and precision. In order to allow for adequate coverage of the diversity of the fisheries, a large sample is necessary 
Table V. Reported average catch rates by gear day (kg/day) for 2009.

Tableau V. Moyenne du taux de prises reportées par moyen de pêche et par jour ( $\mathrm{kg} / \mathrm{jour}$ ) pour 2009.

\begin{tabular}{|l|c|}
\hline Gear type & Catch rate \\
\hline Gill net & 1.9 \\
\hline Hook and line & 1.66 \\
\hline Upright basket trap & 2.17 \\
\hline Cast net & 1.79 \\
\hline Horizontal cylinder trap & 1.18 \\
\hline Spear gun & 2.76 \\
\hline Hand spear & 1.61 \\
\hline Lift net & 2.21 \\
\hline
\end{tabular}

from different areas of the basin. In order for the data to be representative for the fisheries, the sample needs to be random and sufficiently large. At the start of the fish catch monitoring a decision was made that the best approach would be to have continuous data collection for selected households, i.e. sampling in space, but not in time. This was done to allow observing changes in fishing patterns over time (during the month) but also to facilitate data collection. Once initiated, this approach was maintained to ensure that the timeseries remained comparable. For the households survey $(\mathrm{IHI})$ a monthly time-frame was established, as a more detailed breakdown isn't possible for a recall survey, while for the $\mathrm{DCL}$, daily fishing activities are recorded. This approach creates a conundrum in that a large random sample for a recall survey like the $\mathrm{IHI}$ is easy to implement, while for the DCL this is practically impossible. The DCL places much higher demands on the household, and cannot be implement with a high number of random sampled households and therefore by definition needs to be treated as a panel survey.

Implementing the detailed DCL survey as a panel survey makes the most sense to monitor changes in the fisheries and for this a large sample is not necessary. At the same time, the $\mathrm{IHI}$ survey can be used to assess general trends and a rough catch estimate for the total catch, while the $\mathrm{VCl}$ is used for providing qualitative information on fisheries issues (e.g. fisheries management) and catch locations. The 3 components complement each other and this leads to better information than if only one component would be implemented.

Relying solely on community science, i.e. recall surveys and household catch logbooks without independent direct measurements of catches may seem a gamble, but the general method of using household logbooks or interviews to obtain Local Ecological Knowledge (LEK) have proven themselves elsewhere (Johannes, 1993; Baird, 1998; Baird et al., 1999; Poulsen \& Valbo-Jørgensen, 2000). It should be kept in mind that a fisherman generally is just as interested to get the facts right as any scientist; there is often a sense of pride as well as commitment to collaborate in community based data gathering. Obviously what is necessary is a system that allows for a certain level of validation. Poizat \& Baran (1997) compared the knowledge of fishermen with gill-net sampling in the Fatala River estuary, in Guinea, West Africa. They found that there was "good coherence between fishermen's answers and gill-net sampling results" and supported the idea of 
using fishermen's knowledge as a source of ecological information and even for providing catch information. Visser (2004) also found a good correlation between the timing of known migration patterns with observed peaks in catches as recorded in catch logbooks, with for some species a $90 \%$ match. In addition the logbook data in that study was found to be consistent between participating fishermen, indicating that they were correctly reporting the species catches.

\subsection{Sampling design}

The inclusion of villages for the $\mathrm{IHI}$ and DCL surveys that are more dependent on fisheries has implications for the representativeness of the data. Nevertheless, any trends found for these villages with a higher than average dependence on fisheries are also valid for other villages. The main consideration of the survey and sample design was to allow monitoring of longterm trends and eventually the level of impact from NT2 operations in key fishing areas, not the accurate estimation of the fishing parameters for all villages.

Over the course of the survey period no changes were made to the village coverage or basic methodology (survey forms or data collection methodology) for the DCL and IHI surveys as not to interrupt the time-series. However, as indicated in this paper, some changes were made to ensure data quality. Most changes were related to Quality Assurance and Quality Control (QA/QC) both for data collecting and data entry while streamlining the process of validating data collected, reducing the time between data collection and analysis, as well as database related improvements, e.g. translation of Lao language entries and coding of responses into categories for easier analysis.

A major issue with the implementation of logbook surveys (or any type of panel survey) is the high attrition rate of participants. Any change in the composition of the households participating in the survey carries the risk that the data is affected. More than $65 \%$ of the households that were selected at the start of the DCL survey in 2006 are still involved at the beginning of 2014. Most of the changes in original selected households occurred in the first year of implementation and again directly after the resumption of the survey in 2008. This indicates the period when sample households realised the workload involved and subsequently that the survey would last beyond a single year.

Instead of accepting a reduction of the sample size, households are replaced with a compatible household (in terms of overall catch, effort and dependency on fisheries as a livelihood). This is focused on minimising changes in the composition of the overall sample, with the option to only consider the original households for analysis, but generally relying on median values for fishery parameters for groups of households from the same area.

The overall attrition rate is very low for a survey that is implemented for 8 years, with on average less than 6 households having to be replaced each year. This is a major accomplishment and key in establishing a consistent time-series. 


\subsection{Accuracy and precision of data collected}

Working with fishing households as the main source of information means that extra precautions have to be taken to ensure that the resulting data is as accurate as possible. Data collected through household interviews or fish catch logbooks is rarely exact. Furthermore, asking for too much detail may actually lead to less accurate information as household monitors may feel obliged to fill in all the required information and in the process make data up.

As most statistical texts on survey design point out (Fowler, 2009), survey design tends to aim for optimisation of both precision and accuracy. However achieving a high precision and accuracy is expensive. The DCL survey is designed to obtain data in a consistent way. It is more important that the precision of data collected in 2006 is the same as that for 2013, than to introduce improvements to achieve a higher accuracy. This means that the methodology has focussed on consistency; without changes to the actual methods since the start of the implementation. It also means that it isn't a priority to assess to what extent the data collected represents the 'real' catch or effort, i.e. how accurate the data collected represents the true values. The data isn't used to estimate the overall catch, but rather to assess changes in the fisheries. This means that the main challenge is to keep the attrition rate of households from the sample as low as possible and the precision constant. The data is treated as a panel survey where long-term changes in fishing patterns are compared between groups of fishing households from the two fixed fishing zones in the Xe Bangfai: Lower and Upper-Middle Xe Bangfai, with a distinction made between households from riparian and hinterland villages for each zone.

What is most important is that the results of the survey are replicable, even though they may not be accurate. Using interviews or logbooks already forgoes a high level of accuracy and this is further exacerbated by introducing additional bias in using a non-random household sample. Implementing a complex survey instrument like the DCL makes this is unavoidable. Households need to be willing to participate to ensure the highest level of cooperation. Data reported by households generally is taken at face value and there is in principle no non-eligible data, except for the first 3 months of data from 2006. These data were never included in the analysis, as data from this start-up phase contained many mistakes and irregularities. Beyond this start-up phase households are expected to be consistent in what and how they report their catches over the time-series. Because households were selected based on their willingness and capacity to collect data, chances that they report catches truthfully are increased. Some irregularities in the reported catch and effort have occurred and are discussed with the participating households. If inconsistencies cannot be explained or if the household is no longer willing to participate, the household is replaced.

Collecting fish or other aquatic animals (OAA) for household consumption is often not considered to be fishing by the head of the household and 
was frequently left out of the reported data during 2006-2007, until data collectors convinced households that collection of fish and OAA by other household members needs to be reported too. It is necessary to stay vigilant about this aspect of the data collection whenever households are replaced for the logbook survey, or when for the $\mathrm{IHI}$ survey the households are resampled at the beginning of each year. Because of these factors the available data for the first year of the survey (2006) has a higher variation and probably a lower accuracy than that collected later on with regards to OAA.

The results from the verification survey indicate that the households involved in the DCL seem to be better in keeping their fish catches stable between seasons than the average randomly selected household. The DCL data can be used as indicator for change in the fishery, but the difference between the average catches and those reported by the DCL households means that any calculated changes in fishery patterns cannot simply be extrapolated to the larger fisher population. If anything, annual changes in fish catches may actually be higher for households in general as they cannot (or choose not to) keep catches at consistent levels throughout the year.

The available data from the verification survey suggest that there is a seasonal influence and that overall the level of under estimation by the DCL data of the actual catches is highest during the wet season and turns into an over estimation during the dry season. Even though the findings of the verification survey emphasise that the DCL data cannot be used to estimate the actual total catch for all households in the Xe Bangfai basin, it still provides a valid basis to assess annual and seasonal trends in the fishery for households with a more than average dependence on fisheries.

\subsection{Baseline results (2006-2009)}

The data presented in this paper clearly shows the seasonality of the fisheries and large differences in the total reported catch. Mainstream habitats are more important during the dry season, while floodplains and tributaries are of importance during the wet season. Daily catches are highest in tributaries and streams, while mainstream habitats provide more than $2 / 3$ of the total catch. Although this seems a contradiction, this is mainly because tributaries and streams are targeted mainly at the end of the wet season when fish migrate back from the floodplains to the main river channel. As such, the Xe Bangfai is a typical floodplain driven fisheries, with considerable inputs from the Mekong in the early wet season with a peak in the catches at the onset of the wet season and again at the onset of the dry season.

Gillnet is preferred by most fishing households because it is non-selective passive gear, i.e. it can be set and left, while most other gears with a high catch rate either are active gears, i.e. they need to be wielded for fishing (spears, lift net hook and line) or have a very distinct location and time they can be used (Upright basket trap). Therefore for the largely part-time fishing employed in the Xe Bangfai, gillnets are the most efficient gear for most fishing households. 
Since all data is obtained from commercial fisheries it is difficult to reach any definite conclusions on catch levels and trends, as fishermen tend to optimise their catches by 'chasing the fish'. Taking into consideration annual fluctuations in the catch because of differences in flooding patterns, reflected in the total reported catch, the data points at differential decline for some species, possibly connected to increasing fishing effort or changes in the aquatic ecosystem.

The absence of any clear trend in the available baseline data time-series presented in this paper for 2006-2009 emphasises the influence of a strong flooding year (2005) on fish catches in subsequent years as the main driver for year-on-year changes.

NTPC considered the availability of a fisheries baseline of immense importance and considerable efforts were made to ensure baseline surveys were implemented for the project areas in the 5 years running up to the start of commercial operations. Although a baseline with a longer time series would be desirable, organizational and practical constraints make it difficult for baseline monitoring to start before a project is officially approved and before financial close. Hopefully the experiences described in this article may lead to more hydro power projects prioritizing collection of baseline data.

\section{CONCLUSION}

The experience in implementing a Fish Catch Monitoring system for the
Xe Bangfai basin may be summarised in a number of recommendations with general applications:

- a dedicated field team is essential to safeguard the quality and consistency of the FCM implementation;

- limited scope rapid appraisal surveys based on community mapping of fishery resources provide an excellent entry point for establishing the main markers for an FCM system;

- establishing a fisheries baseline for hydro-power projects is an essential part of impact assessment with a duration of at least 5 years, where possible, supplemented with control areas not influenced by project operations to increase utility of the data set;

- quantitative FCM surveys should always be implemented alongside more informal local knowledge surveys that can provide background information on fisheries and perceived trends;

- recall surveys with a long recall period only have a limited utility, they work best when the recall period is short, otherwise they tend to reflect perception of change;

- villages and households should be selected randomly whenever possible to allow the results of the FCM to be representative for the fisheries as a whole, if key fisheries need to be monitored, this can be done through a logbook based panel survey; and

- household logbook systems can provide a cost-effective and valuable tool for assessing trends and changes in the fisheries. 


\section{ACKNOWLEDGEMENT}

This research has been conducted at Nam Theun 2 Power Company in Lao PDR whose shareholders are Électricité de France, Lao Holding State Enterprise and Electricity Generating Public Company Limited of Thailand. We would like to thank NTPC management, E\&S Director Ruedi Luthi for supporting the preparation of this paper and especially Jean-Pierre Katz and Jean Copreaux whose support during their tenure encouraged us to develop our thoughts on how best to share lessons learned, the Downstream Program Team, led by Francois Demoulin and Richard Peary and last, but certainly not the least, all households that have been part of the fisheries surveys.

\section{REFERENCES}

Baird I.G., 1998. Preliminary Fishery Stock Assessment Results from Ban Hang Khone, Khong District, Champasak Province, Southern Lao PDR. Technical report on environmental protection and community development in the Siphandone Wetland of Champassak province. Funded by the European Union and implemented by CESVI, $112 \mathrm{p}$.

Baird I.G., Inthaphaisy V., Kisouvannalath P., Vongsenesouk B. \& Phylavanh B., 1999. The Setting Up and Initial Results of a Villager-Based System for Monitoring Fish Conservation Zones in the Mekong River, Khong District, Champassak Province, Southern Lao PDR. Technical report on environmental protection and community development in the Siphandone Wetland of Champassak Province. Funded by the European Union and implemented by CESVI, $41 \mathrm{p}$.
Descloux S., Guédant P., Phommachanh D. \& Luthi R. Main features of the Nam Theun 2 hydroelectric project (Lao PDR) and the associated environmental monitoring programme. Hydroécol. Appl. 19 (same issue).

FAO, 1999. Guidelines for the routine collection of capture fishery data. Prepared at the FAO/DANIDA Expert Consultation, Bangkok, Thailand, 18-30 May 1998. FAO Fisheries Technical Paper. No. 382, Rome, FAO, 1999, 113 p.

Fowler F.J., 2009. Survey Research Methods. Sage Publications. Applied social research methods series, $201 \mathrm{p}$.

de Graaf G.J., Born B., Uddin K. \& Marttin F., 2001. Floods, Fish and Fishermen. Eight years experiences with flood plain fisheries, fish migration, fisheries modelling and fish bio-diversity in the Compartmentalisation Pilot Project, Bangladesh. Technical report for the Compartmentalisation Pilot Project, Bangladesh, $127 \mathrm{p}$.

Hoggarth D.D., Cowan V.J., Halls A.S., Aeron-Thomas M., McGregor J.A, Garaway C.A., Payne A.I. \& Welcomme R.L., 1999. Management guidelines for Asian floodplain river fisheries. Part. Summary of DFID research. FAO Fisheries Technical Paper No. 384/2, Rome, FAO, 1999, $117 \mathrm{p}$.

Hortle K.G. \& Bush S.R., 2003. Consumption in the Lower Mekong Basin as a Measure of Fish Yield. In: New Approaches for the Improvement of Inland Capture Fishery Statistics in the Mekong Basin. FAO RAP Publication 2003/01, 76-82.

Johannes R.E., 1993. Integrating traditional ecological knowledge and management with environmental impact assessment. In: Inglis J.T. (Ed.). Traditional Ecological Knowledge: Concepts and Cases, 33-41. 
Junk W.J., Bayley P.B. \& Sparks R.E., 1989. The flood pulse concept in river-floodplain systems. In: Dodge D.P. (Ed.). Proceedings of the International Large River Symposium. Can. Spec. Publ. Fish. Aquat. Sci. 106 : 110-127.

Kolding J., 1989. The fish resources of Lake Turkana and their environment. Thesis forthe Cand. Scient degree in Fisheries Biology and Final Report of KEN 043 Trial Fishery 1986-1987, University of Bergen, $262 \mathrm{p}$.

Kottelat M., 2001. Fishes of Laos. WHT Publications (Pte) Ltd, Colombo, Sri Lanka, 198 p.

MRC, 2003. Mekong Fish Database version 2003. CD-ROM. Mekong River Commission, Phnom Penh, Cambodia.

Phan T.L., Pham M.P., Visser T.A.M., Sjorslev J.G. \& Hortle K.G., 2003. Inland fisheries activities and fish consumption in TraVinh Province, Viet Nam. MRC Conference Series 4 : 127-139.

Phonvixay S., 2013. An introduction to the Fisheries of Lao PDR. Mekong Development Series No. 6, Mekong River Commission, Phnom Penh, Cambodia, 62 p.

Poizat G. \& Baran E., 1997. Fishermen's knowledge as background information in tropical fish biology: a quantitative comparison with fish sampling results, Environ. Biol. Fish. 50 : 435-449.

Poulsen A.F. \& Valbo-Jørgensen J., 2000. Fish migrations and spawning habits in the Mekong Mainstream - a survey using local knowledge. AMFC Technical Report. Mekong River Commission.
Reyntjes D., 1997. Handbook for Fisheries Officers. Lake Fisheries Development Project Phase II, working paper No. 24, $92 \mathrm{p}$.

Sjorslev J.G., 2000. Fisheries survey, LuangPrabang Province Lao PDR. LARReC Research Report No. 1 NAFRI and MRC Fisheries Component, Vientiane, Lao PDR, 45 p.

Stamatopoulos C., 2002. Sample-Based Fishery Surveys - A Technical Handbook. FAO Fisheries Technical Paper: No. 425, FAO Rome, 76 p.

Suntornratana U., 2002. Fisheries Survey of the Lower Songkhram River Basin. Draft Report. AMCF Component, Mekong River Commission Fisheries Programme and Department of Fisheries, Thailand, $42 \mathrm{p}$.

Visser T.A.M., 2003. Collecting Fishery Statistics for Inland and Coastal Fisheries. SEAFDEC report, $180 \mathrm{p}$.

Visser T.A.M., 2004. Analysis of Migration Monitoring Logbook Survey. Quality assessment, comparison with Local Ecological Knowledge Surveys and obtaining optimal sampling frequency for routine catch assessment. AMFC Technical Report. Mekong River Commission, 62 p.

Welcomme R.L., 1975. The fisheries ecology of African floodplains. CIFA Tech. Pap. (3), $51 \mathrm{p}$.

Ziv G., Baran E., Nam S., Rodríguez-Iturbe I. \& Levin S.A., 2012. Trading-off fish biodiversity, food security, and hydropower in the Mekong River Basin. Proceedings of the National Academy of Sciences 109, No. 15 : 5609-5614. 